EDITORIAL

\title{
A Tribute to Professor Gustavo Hoecker Salas
}

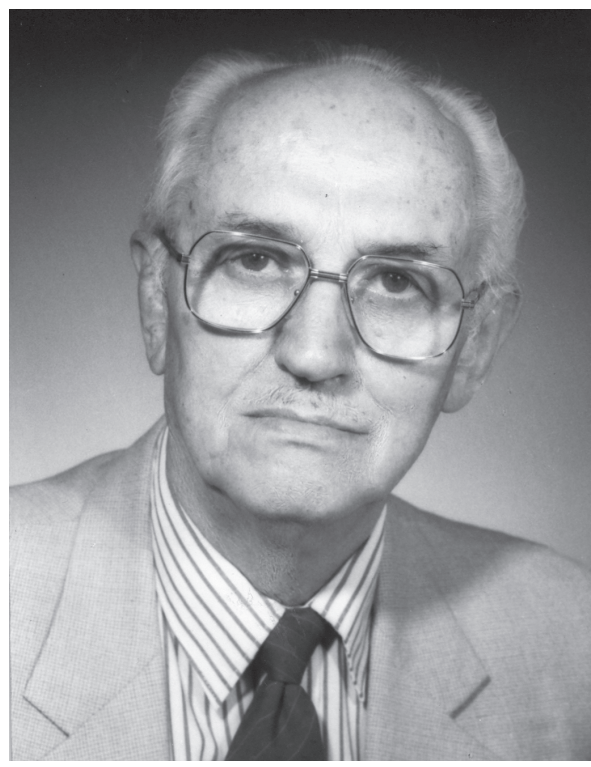

$P^{r}$ rofessor Gustavo Hoecker Salas was born in Rere, in December 1915. Rere is about $500 \mathrm{~km}$ south of Santiago, Chile, just $10 \mathrm{~km}$ from the Bio-Bio River. He obtained his degree in Veterinary Medicine at the University of Chile, in 1943.

He was an important mentor for at least 20 investigators, most of them scattered around the world in many different universities, some of them in Chile. Alicia Ramos (his wife and fundamental scientist associate), Danko Brncic, Pablo Rubinstein, Fernando Morgado, Eduardo Bustos, Carlos Moreno, Fidel Zavala, Mario Mitnik, Jorge Valenzuela, Sigmund Fisher, Isaac Kirschborn, Harry Schanzer, Humberto Maturana, Marcela Contreras, Rodrigo Mora, Jorge Fernández, Carlos Valenzuela and Arturo Ferreira are just some of them.

Professor Hoecker used to say "In science, as in poetry, it is not enough to say I am a poet, if the other poets do not say it. And they will say it only if the poetry is written. Thus, unwritten science does not exist. It will be blown with the wind. Thus, we scientists have no alternative but to be good writers". In this spirit, Gustavo Hoecker published over 100 scientific papers in the most prestigious Journals, such as Nature y Proceedings of the National Academy of Sciences (USA), among many others. Most of this work was carried out at a time when supports such as the Internet and wellestablished national funding for research did not exist or were just emerging.

Hoecker's contributions to Chilean science were not only scientific papers published in first-class international journals. Thus, "el Maestro", as we, his students called him, played an essential role in the consolidation of the Biology Department at the Faculty of Medicine and in the creation of the Faculty of Science in 1965, of which he was the first dean, both fundamental contributions to the University of Chile.

At a national level, he was a founding member of the Chilean Immunology Society, the Chilean Genetics Society and the Chilean Academy of Sciences. He also played a central role in the creation of the National Scientific and Technologic Council (CONICYT-CHILE).

A distilled overview of Hoecker's main scientific contributions will be necessarily focused on the mouse Major Histocompatibility Complex (MHC). This is a small genetic segment localized in chromosome 17 in this species. Before the contributions of Gustavo Hoecker and George Snell (Nobel Prize in Medicine, 1980), this genetic segment was known as the "H-2 locus", somehow involved in the control of acceptance or rejection of allogeneic transplants (usually skin). Gustavo Hoecker and George Snell, working together and also independently, defined that this genetic segment is not a locus (namely, the chromosome place that harbors a single gene), but rather a genetic complex where many genes are located. Hoecker's papers defined the possibility that the distance between the $H-2$ telomeric and centromeric limits was such, that crossing-over was possible at many points, increasing the possibilities of phenotypic expression. Thus, the name of " $\mathrm{H}-2$ complex" was soon adopted.

Although at that time (mainly the 1950s and 1960s), the definition of the gene products coded in $\mathrm{H}-2$, was just emerging, Hoecker's work anticipated that these products should conform the molecular terms that govern the recognition of "self and non-self". Hoecker's work also contributed to the understanding of the extreme polymorphism that $H-2$ genes display. Indeed, he frequently defined the complex as the "most polymorphic ever known to man". He also advanced that the control of acceptance or rejection of transplants was just a practical correlate of a broader capacity of this complex, that is the ability to recognize, as non-self, an hallucinating variety of exogenous (bacteria, protozoa, virus, etc) and endogenous (mainly tumors) aggressors.

In spite of the enormous evolutionary distance between mice and humans, the basic structural and functional properties of murine $\mathrm{H}-2$ and its human HLA counterpart, have remained meticulously conserved. Thus, Hoecker's studies on $H-2$ were premonitory and have guided the advance in the HLA knowledge.

Taken altogether, Hoecker's studies provided important information for the subsequent enormous strides that many laboratories in the world have made in the knowledge of this complex in both mice and humans. We now know that the MHCs of the species play central and directive roles in immune recognition, coding specialized molecules to fulfill that purpose. Among many other molecules coded there, two classes are key in the capacity of antigen presenting cells (APCs) to stimulate T lymphocytes. Thus, APCs intracellularly load onto these cells the foreign peptides and then expose them on their surfaces. There, both $\mathrm{T}$ helper and cytotoxic cells 
recognize the foreign peptides, within the context of the self-MHC molecules and, normally, robust immune responses are generated, aimed at eliminating the aggressor. This strict immunogenetic restriction was at the core of Hoecker's inspired research.

Present immunological knowledge has been acquired based on the contributions of many scientists. Thus, our MHC knowledge is no exception to this rule. In its context, any serious study reviewing its history will necessarily mention the work of Hoecker and his many collaborators. It is obvious then that there were many potent reasons to award the Chilean National Science Prize, in 1989 to this remarkable academic and scientist.

\section{WHAT HAS BEEN WRITTEN ABOUT GUSTAVO HOECKER BY SOME OF HIS PEERS AND STUDENTS?}

Professor Amador Neghme, distinguished Parasitologist, Past Dean of the Faculty of Medicine, University of Chile: "...even as a student, he was a teacher and an investigator, first with that great biologist, historian and humanist, Professor George Nicolai. Later, he followed Professor Juan Noé's teachings, a founder of biologic research in Chile. Thus, he became a biologist and worked with Professor Gabriel Gasic on avian leukemia. For that purpose, he received economic support from the Chilean Poultry Production Society, the first documented contribution from the private sector to science in Chile. Because there were no doctoral programs in Chile at that time, he always recruited undergraduate students, in particular from the Faculty of Medicine, at the University of Chile, for his research".

Professor Sergio Lecannelier, distinguished Pharmacologist, Past Dean of the Faculty of Medicine, University of Chile: “... I felt that Prof. Hoecker carried two passions in his soul: one, the wish to satisfy his scientific curiosity; but without forgetting the other, to contribute to the growth of his alma mater, the University of Chile, the main motor for his deepest inspirations".

Professor Jan Klein, internationally recognized immunogeneticist from the Max- Plank Institute, Germany: "The mouse, in particular the domesticated variety, the laboratory mouse, has probably brought more people together than many a Lonely Hearts Club. They get together, and what do they talk about? Not about the weather, not about politics, but about mice. Thousands of scientists have made acquaintances, struck up friendships, and, yes, even found mates through mice. It was through mice that we got to know Gustavo Hoecker. We knew about him long before we met: his paper on the serologic similarity between $\mathrm{H}$-2 and $R h$ was a classic, and anyone who was seriously interested in the $H-2$ complex had to read all his papers. Therefore, when our paths finally crossed, there were no awkward moments for choosing the right topic for discourse. It was as if we had known him for ages and the meeting was just an opportunity to continue an interrupted conversation, on a subject that interested us all".

The first genetically standardized mouse facility in Latin America: In 1954, Gustavo Hoecker created the first Mouse Facility for Genetically Standardized Animals in Latin
America (Faculty of Medicine, University of Chile). This is where some of his most important publications were generated. Although he was convinced of the experimental value of the mouse model in research, he had a profound respect for the sensitivity of these creatures, and animals in general. Perhaps, inspired by his primary training as a veterinarian, he used to say: "If you have not lived with a dog at home, you have lost an important part of life".

George Snell, when he received the Nobel Award in 1980, at the Karolinska Institute: “.... Gustavo Hoecker's experiments allowed me to understand the complexity of the $\mathrm{H}-2$ chromosome segment in mice". These discoveries were premonitory to understand the human homolog complex, HLA.

Fidel Zavala (Johns Hopkins University) and Rodrigo Mora (Harvard Medical School), two of his many excellent trainees: "After working with Peter Gorer in London, and later with George Snell in Bar Harbor, Gustavo Hoecker became a distinguished member of a unique group of researchers, referred to by Peter Medawar as the very exclusive $H-2$ club, which was dedicated to the characterization of the immune mechanisms and antigens mediating the rejection of tumor transplants, i.e. histocompatibility antigens. Hoecker demonstrated that these antigens are encoded by a complex genetic system consisting of several loci and multiple alleles that are expressed in most tissues and cell types.

Gustavo Hoecker had the privilege of witnessing and enjoying the explosive change that occurred to this research area in the late 1970s and 1980s, when it was established that these histocompatibility antigens were in fact the product of a complex system of genes that govern fundamental aspects of T-cell responses, i.e. the induction and effector phases of $\mathrm{T}$ cell mediated immunity. The work of Hoecker and collaborators were the first steps in unveiling this fascinating biological system that dramatically changed our understating of immune responses.

In addition to his groundbreaking scientific discoveries, Prof. Hoecker was an exceptionally wise and generous mentor. Each conversation or discussion with him was an opportunity to learn, not only about science, but also about life in general. He valued original thinking and always encouraged people to challenge paradigms. Moreover, he was very open to considering other people's ideas, even if they were not in agreement with his views. Prof. Hoecker's extraordinary enthusiasm and passion for science were, and continue to be an inspiration for all people who were fortunate to know and interact with him. As former mentees or disciples, we can express our gratitude by trying to transmit, with a "Hoeckerian spirit", his heritage of generosity, enthusiasm and passion for science to the future generation of scientists.

Pablo Rubinstein, Director of the New York Blood Center. "Professor Gustavo Francisco Hoecker (Pancho, or the Prof) taught Biology and Genetics in the Medical School, University of Chile, and conducted world-class research into the immunogenetics of $H-2$, the major histocompatibility genes in mice, when I entered Medical School in March, 1955. His course was no less demanding than Anatomy, but 
projected infectious enthusiasm for the mechanisms of life such that many students were infected, some, incurably. Pancho's course required thought beyond study, and induced changes that enhanced the infection. Beginning in 1956, I had the good fortune to assist in his and Dr. Olga Pizarro's Laboratory, where immunogenetic analyses soon disclosed the complexity of major histocompatibility gene(s) as systems of closely linked genes, antedating findings in Homo sapiens by a decade. Apprenticeship there was not easy, but the rewards were permanent: all of Hoecker and Pizarro's work was fully confirmed (not quite the case for many first rate Labs of the period), a life of curious wonder and exhilarating work was disclosed, exposure to broad areas in science, medicine, logic, philosophy, music, ... and intelligent savoir faire: Pancho was an exceedingly well read man, respectfully cherished by scientists worldwide. His name opened the doors for use to universities, research establishments and scientists in our field all over the world. But his biggest gift was the urgent need for truth: experiments repeated and their accuracy challenged, conclusions discussed and criticized, seemingly beyond reasonable limits, "we are trusted only until the first slip", "life is short, the Art long, opportunity fleeting, experiment dangerous, judgment difficult" (an unforgettable Hippocratic Aphorism), progress comes "en trabajando" (literally, "in working"). He judged well, reflected by 32 first-rate Hoecker publications still listed in PubMed and a delightfully personal book on Mendelian genetics, edited by the University of Chile. But Pancho Hoecker was more than a scientist and mentor: at the dedication of the University's cyclotron building (a USA donation, obtained by him while he was the first Dean of the Faculty of Science, University of Chile) early after the end of President Allende's Government, our Prof, in his speech, said he was grateful to have been born in Chile, a country where dictatorships last the time it takes a tree to give fruit.

His being Chilean honors Chile and Chileans."

Intellectual interaction with Gustavo Hoecker. It was always a challenge. It was a must to be prepared. When he reviewed a manuscript in preparation, it meant destruction. Thus, the many new versions were progressively better.

"Each human being is a single edition": One of his most striking statements. Based on rigorous genetic considerations that he envisaged through the extremely polymorphic MHC complex, each human being is a single edition. Most likely, there will never exist, or never has existed, two identical human beings. Not even clones. Random mutations and multiple other genetic phenomena will prevent it.

Finally, Gustavo Hoecker had a special finely tuned sense of humor. Each one of his sayings had a particular profound meaning. Here we have tried to translate just a couple of them:

"It is unwise to bleed among sharks".

"Each human being is a single edition. However, in this laboratory we are all equal. Only that some of us are more equal than others".

Gustavo Hoecker died on March 19, 2008

Arturo Ferreira \& Carlos Valenzuela, Guest Editors Manuel J. Santos, Editor-in-chief.

Santiago; Chile, August 2010

P.S. In this section we have used the acronym $\mathrm{H}-2$, to represent the $\mathrm{MHC}$ This is how Gustavo Hoecker used it in his papers. More recently, a change in nomenclature has been proposed and reluctantly accepted. This MHC should now be termed simply as $H 2$, in agreement with the HLA acronym. 
